\title{
The Efficacy of Yttrium-90 Radiosynovectomy in Patients with Camptodactyly-Arthropathy-Coxa Vara-Pericarditis Syndrome
}

\author{
Yttrium-90 Radyosinovektominin Kamptodaktili-Artropati-Koksa Vara-Perikardit Sendromlu \\ Hastalarda Etkinliği
}

\author{
Sulaiman Mohammed Al-Mayoufl, Nora Almutairil, Khalid Alismail2 \\ IKing Faisal Specialist Hospital and Research Center, Clinic of Pediatric Rheumatology, Riyadh, Saudi Arabia \\ 2King Faisal Specialist Hospital and Research Center, Clinic of Musculoskeletal Radiology, Riyadh, Saudi Arabia
}

\begin{abstract}
Objective: Camptodactyly-arthropathy-coxa-vara-pericarditis (CACP) syndrome is an autosomal recessive disorder caused by mutations in PRG4 gene that encodes for proteoglycan 4, the main lubricant for joints and tendon surfaces. It is a noninflammatory arthropathy, characterized by joint effusions and synovial hypertrophy. So far, there is no effective treatment for this disorder. To evaluate the effectiveness of yttrium-90 radiosynovectomy in arthropathy of patients with CACP syndrome. Methods: Consecutive patients with CACP syndrome were prospectively evaluated at the enrollment and 3 months after the right knee injection with yttrium-90. The outcome variables were patient/parent and physician's global assessment measured by a 3-point scale, right knee swelling and range of motion on a 3-point scale, in addition to magnetic resonance imaging (MRI) assessment of the right knee for bone, cartilage, fluid, synovial hypertrophy and soft tissue changes.

Results: Six (three boys, three girls) patients with a mean age of 12 years and mean follow-up duration of 8.5 years completed a single right knee intra-articular yttrium-90 injection with $5 \mathrm{mCi}$. The procedure was well tolerated without adverse events apart from mild and transient joint pain in two patients. There was a minimal radioisotope leakage to soft tissue in two patients. During the 3-month follow-up interval, there was no improvement in the outcome variables. Patients and parents did not notice favorable therapeutic effects and global physician assessment was unsatisfactory. There was no difference in knee joint swelling or range of motion. Furthermore, MRI findings were unchanged. However, there was a minimal increase in synovial fluid post injection.

Conclusion: Yttrium-90 radiosynovectomy seems to be a safe and well tolerated procedure, however, it did not show a beneficial therapeutic effect in arthropathy of CACP syndrome with the given dosage and interval. Studies including a larger number of patients and probably repeated injections are needed to derive satisfactory results about the effectiveness of yttrium-90 in CACP syndrome patients.

Keywords: Camptodactyly-arthropathy-coxa-vara-pericarditis, radiosynovectomy, yttrium-90
\end{abstract}

Address for Correspondence: Sulaiman Mohammed Al-Mayouf MD, King Faisal Specialist Hospital and Research Center, Clinic of Pediatric Rheumatology,

Riyadh, Saudi Arabia

Phone: +996114427761 E-mail: mayouf@kfshrc.edu.sa Received: 26.12.2016 Accepted: 14.02.2017

${ }^{\circ}$ Copyright 2017 by Turkish Society of Nuclear Medicine

Molecular Imaging and Radionuclide Therapy published by Galenos Yayınevi. 


\section{Öz}

Amaç: Kamptodaktili-artropati-koksa vara-perikardit (CACP) sendromu eklem ve tendon yüzeylerinin ana lubrikanı olan proteoglikan 4'ü kodlayan PRG4 genindeki mutasyonlara bağlı bir otozomal resesif hastalıktır. Eklemde efüzyon ve sinovyal hipertrofi ile karakterize non-enflamatuvar bir artropatidir. Henüz bu hastalığın etkin bir tedavisi yoktur. Amacımız CACP sendromlu hastaların artropatisinde yttrium-90 radyosinovektominin etkinliğini araştırmaktır.

Yöntem: CACP sendromu tanısı alan ardışık hastalar tanı anında ve sağ dize yttrium-90 enjeksiyonu uygulanmasından 3 ay sonra prospektif olarak değerlendirildiler. Sonuç değişkenleri 3-puanlı skala üzerinden hasta/ebeveyn ve doktor genel değerlendirmesi, 3-puanlı skala üzerinden sağ diz ödemi ve hareket aralığı ve kemik, kıkırdak, sıvı, sinovyal hipertrofi ve yumuşak doku değişiklikleri açısından sağ diz manyetik rezonans görüntülemesi (MRG) idi.

Bulgular: Ortalama yaşı 12, ortalama takip süreleri 8,5 yıl olan altı hastaya (üç erkek, üç kız) tek sefer sağ dize 5 mCi intraartiküler yttrium-90 enjeksiyonu uygulandı. İslem iki hastada hafif ve geçici eklem ağrısı dışında herhangi bir komplikasyon olmadan iyi tolere edildi. İki hastada yumuşak dokuya minimal radyoizotop kaçağı oldu. Üç aylık takip süresince sonuç değerlerinde iyileşme olmadı. Hastalar ve ebeveynleri olumlu terapötik etki fark etmediler ve genel doktor değerlendirmesi tatmin edici değildi. Diz eklemi ödemi ve hareket aralığında değişiklik yoktu. MRG bulguları değişmedi, ancak enjeksiyon sonrası sinovyal sıvıda minimal artış saptandı.

Sonuç: Yttrium-90 radyosinovektomi güvenli ve iyi tolere edilen bir işlem olarak görülmektedir, ancak verilen doz ve sürede CACP sendromlu hastaların artropatisinde yararlı bir terapötik etki göstermemiştir. Daha fazla hasta içeren ve muhtemelen tekrarlayan enjeksiyonların uygulandığı çalışmalar yttrium-90'ın CACP sendromlu hastalardaki etkinliği ile ilgili gerekli sonuçları sağlayabilir.

Anahtar kelimeler: Kamptodaktili-artropati-koksa vara-perikardit, radyosinovektomi, yttrium-90

\section{Introduction}

Camptodactyly-arthropathy-coxa vara-pericarditis (CACP) syndrome is one of the autosomal recessive familial arthropathies $(1,2,3,4)$. Typically, patients with CACP syndrome present with articular features mimicking most common rheumatic disorders, it is not unusual to mistake these disorders as juvenile idiopathic arthritis (JIA) (5). The locus of CACP syndrome was allocated to a $1.9-\mathrm{cm}$ interval on human chromosome 1q25-31 by homozygosity mapping, and proteoglycan 4 (PRG4) was identified as the responsible gene $(4,6)$. Furthermore, mutations in the gene encoding the secretion of PRG4 lead to synovial hyperplasia and loss of its lubricating function, which is the principal pathological feature of this syndrome $(7,8)$. Currently, there are 15 reported $P R G 4$ mutations $(9,10,11)$.

CACP syndrome is a rare entity, and its worldwide frequency is yet unknown. Although, it has been described in different ethnicities, the diagnosis of CACP syndrome in Saudi families is relatively frequent $(9,12,13,14)$. Unfortunately, there is no available effective treatment yet.

Medical synovectomy (radiosynovectomy) using radioactive isotope is considered as an alternative therapeutic option for different chronic inflammatory arthritis pathologies such rheumatoid arthritis, and osteoarthritis. Radiosynovectomy is also used as an adjuvant therapy in patients with pigmented villonodular synovitis and hemophilic arthropathy $(15,16,17,18,19,20)$. It seems that radiosynovectomy was safe and highly beneficial to children with hemophilic arthropathy. To the best of our knowledge, radiosynovectomy has not been used in CACP syndrome patients. We conducted this study to assess the effectiveness of radiosynovectomy in the treatment of knee arthropathy, using yttrium-90 in patients with CACP syndrome.

\section{Materials and Methods}

Consecutive patients with CACP syndrome seen in pediatric Rheumatology clinic at King Faisal Specialist Hospital and Research Center, (KFSH-RC), Riyadh, between May 2015 and March 2016 were included. All involved patients had thorough history and physical examination and the basic blood tests, including complete blood counts, renal and hepatic profile, as well as magnetic resonance imaging (MRI) of both knees at enrollment and 3 months after the therapeutic intervention. The expert musculoskeletal radiologist performed yttrium-90 intra-articular injection of the right knee under fluoroscopy to ensure that the needle was correctly positioned under aseptic circumstances, and the dosage of yttrium-90 was $5 \mathrm{mCi}$ (Figure 1). Following injection of yttrium-90, frontal and lateral scintigraphy was performed to check the distribution of the radioactive material in the joint. Long-acting glucocorticoids (kenalog $1 \mathrm{mg} / \mathrm{kg}$ ) was injected to reduce the risk of acute synovitis. Furthermore, following the procedure, the joint was immobilized by an elastic bandage and the patient was confined to bed for 3 days.

The outcome variables were the patient/parent and the physician's global assessment, range of motion, and swelling as well as MRI findings of the right knee. The parents/patients and the physician completed the global assessment as measured by a 3-point scale (improved, no change, worse). Right knee swelling and range of motion, 
which was documented by a physical therapist, were assessed on a 3-point scale (improved, no change, worse) in addition to the right knee MRI findings including the bone, cartilage, fluid, synovial hypertrophy and soft tissue changes. Similar assessments were completed 3 months after yttrium-90 intra-articular injection.

All collected data were saved and the confidentiality of the patients protected. Personal identifying data were not collected for this research project. The Research Advisory Council and the Ethical Committee of the KFSHRC approved the study (\#2020023). Informed consent was obtained from each participant.

The results were expressed as mean + standard deviation for continuous variables and percentages for categorical variables. A p value <0.05 was considered as significant. The variables were compared using 2-sample t-tests, chisquare tests and Fisher's exact tests.

\section{Results}

Six (three boys, three girls) CACP syndrome patients with a mean age of 12 (7-20) years and a mean follow-up duration of 8.5 (3-11) years were included. The clinical and genetic findings of all patients were previously described $(10,11,12)$. At the time of enrollment, all patients had bilateral flexion contracture and limited extension of knee joints. Additionally, they had significant swelling of the knee joint with large effusion and thickened rubbery

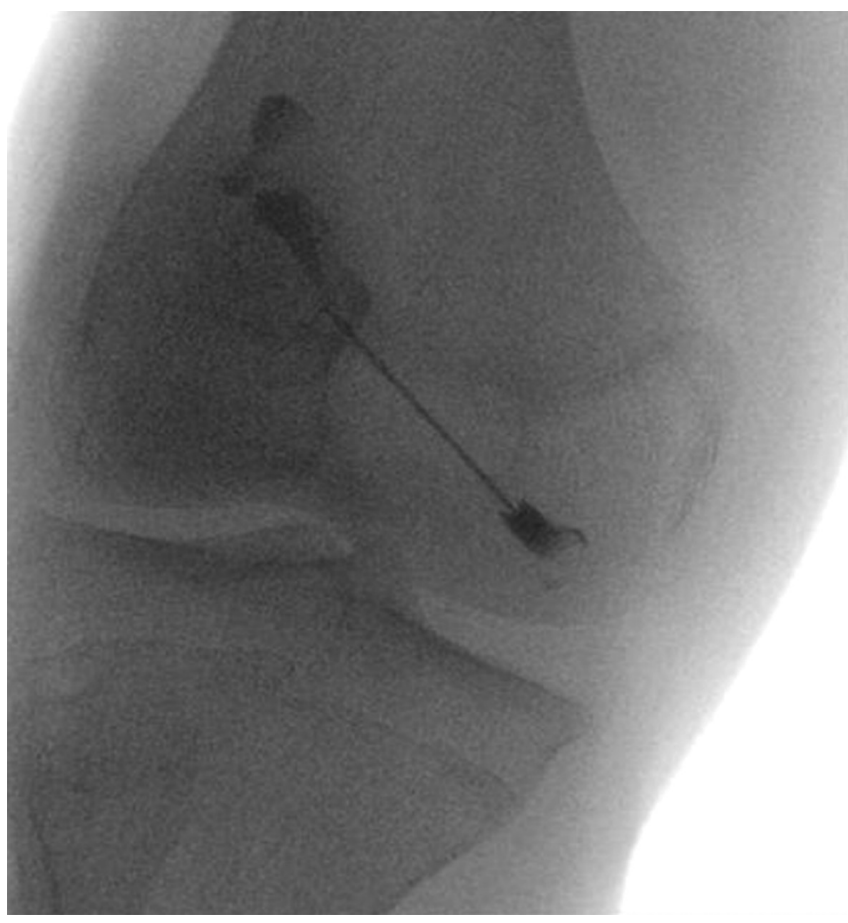

Figure 1. Anterior-posterior oblique projection shows the introduced needle from the medial side with the iodinated contrast synovium. There was no associated pain or tenderness on joint motion.

All patients had a normal complete blood count, renal and hepatic profile and acute phase reactants. MRI prior to yttrium-90 injection showed moderate to severe knee joint effusion with thickened enhanced synovium (Figure 2). The procedure was well tolerated without significant adverse events, gamma camera scans post yttrium-90 injection showed intra-articular homogenous distribution of the radioisotope. However, two patients had minimal leakage to soft tissue (Figure 3).

Outcome variables did not change significantly 3 months after post yttrium-90 injection. The patients and parents did not notice favorable therapeutic effects, there was no significant improvement in the global assessment of the parent/patients. Furthermore, the global physician assessment was unsatisfactory. Additionally, the range of motion of the right knee was almost the same and there

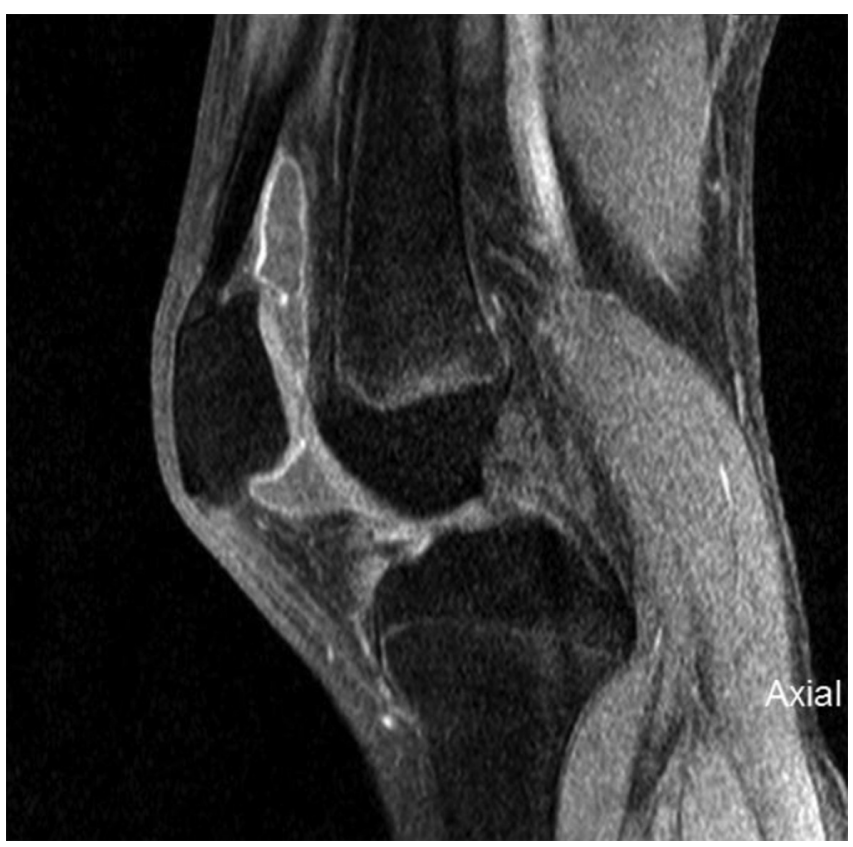

Figure 2. Sagittal T1 fat-saturated weighted magnetic resonance imaging images post contrast injection shows synovial hypertrophy and mild synovial enhancement. Note the amount of synovial fluid
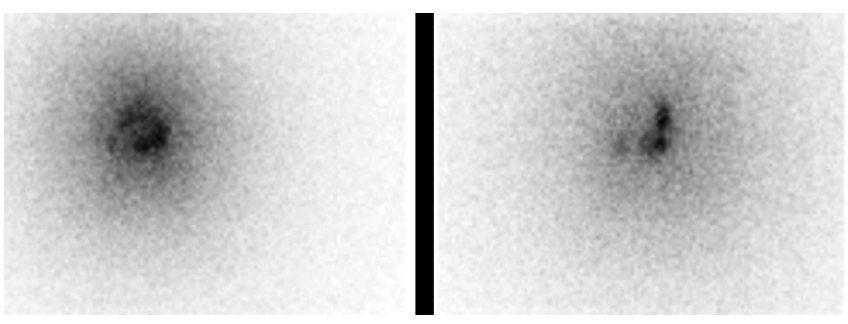

Figure 3. Gamma camera images showing the distribution of yttrium-90 within the joint 
was no difference in knee joint swelling. Moreover, MRI findings remained unchanged. However, there was a minimal increase in synovial fluid post injection (Figure 4).

\section{Discussion}

CACP syndrome is a rare autosomal recessive noninflammatory arthropathy with typical musculoskeletal manifestations, particularly coxa vara and multiple joint contractures.

Affected individuals usually suffer from limited range of motions, mainly the large joints, which might interfere with daily activities. Synovial hyperplasia and loss of the lubricating function is the pathological feature of this syndrome.

Taking the pathophysiology of the disease into consideration, it is predictable that CACP syndrome patients did not respond to anti-inflammatory medications. Actually, some patients with CACP syndrome were misdiagnosed as JIA and were treated with methotrexate and biologic therapy, but without beneficial therapeutic effects.

Despite the availability of effective medical treatment, including systemic anti-rheumatic and local articular treatment of inflammatory arthritis, other therapeutic interventions have been explored particularly in refractory cases. Historically, surgical synovectomy was one of the therapeutic options. However, such an intervention may induce further articular damage and complications.

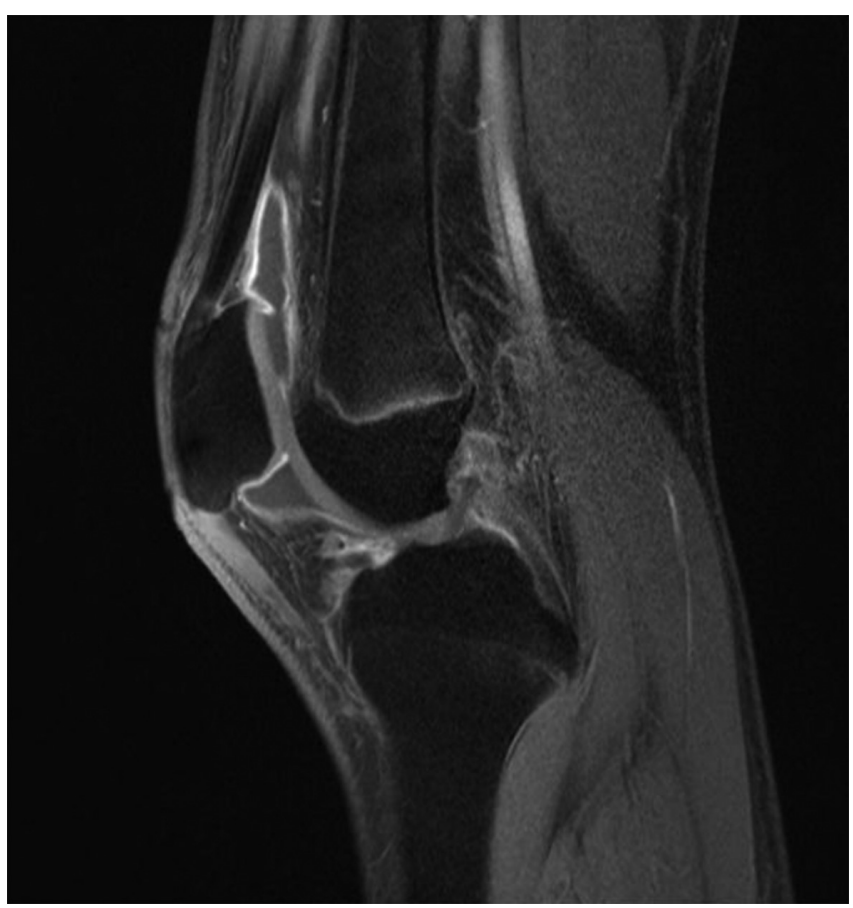

Figure 4. Sagittal T1 weighted fat-saturated magnetic resonance imaging images, post yttrium-90 therapy $2.8 \mathrm{mCi}$ (millicurie)
Radiosynovectomy, which is a less invasive procedure is considered as an alternative therapeutic option for chronic inflammatory arthritis $(15,16,17,18,19,20)$. Radiopharmaceutical excretion is not a concern since the application is local.

We have the privilege at KFSH-RC to follow the largest cohort of children with CACP syndrome (21). Typically, the synovial histopathology showed proliferating epithelium with moderate fibro-collagenous densities and multinucleated giant cells. The long-standing disease is mostly complicated by irreversible articular changes in the form of multiple joints stiffness and contractures, and bone dysplasia such as flattening of the femoral heads, widening of the femoral necks with osteophyte formations and secondary degenerative changes (22). We were hoping that the radioactivity concentrates in the synovium would induce a necrosis of the proliferating synoviocytes. Unfortunately, yttrium-90 radiosynovectomy did not show a beneficial therapeutic effect in our patients. Nonetheless, the procedure was safe and well tolerated. Previous studies of radiosynovectomy in children with hemophilic arthropathy showed encouraging results. However, it is worth mentioning that most patients with hemophilic arthropathy underwent more than one yttrium-90 intraarticular injections $(23,24)$. It is advised to perform radiosynovectomy for hemophilic arthropathy without delay and before the synovitis becomes severe and chronic, otherwise the response to yttrium-90 injections would decrease. Interestingly, other studies revealed that the overall success rate for radiosynovectomy was related to the underlying disease: the treatment was more effective among patients with rheumatoid arthritis and less effective for patients with arthritis of unknown origin (25). Our results might be explained by the difference in the pathology of CACP syndrome. Furthermore, disease stage, particularly the severity of synovial hyperplasia and thickened synovium may be inversely related to the clinical response in addition to the applied dosage and interval of treatment.

\section{Conclusions}

Yttrium-90 radiosynovectomy seems to be a safe and well tolerated procedure, however, it did not show a beneficial therapeutic effect in arthropathy of CACP syndrome with the given dosage and interval. Studies including a larger number of patients and probably repeated injections are needed to derive satisfactory results about the effectiveness of yttrium-90 in patients with CACP syndrome.

\section{Ethics}

Ethics Committee Approval: King Faisal Specialist Hospital and Research Center Ethics Committee approved protocol (Research Advisory Council \#2020023), Informed Consent: Obtained from each patient.

Peer-review: Externally peer-reviewed. 


\section{Authorship Contributions}

Surgical and Medical Practices: Khalid Alismail, Concept: Sulaiman Mohammed Al-Mayouf, Design: Sulaiman Mohammed Al-Mayouf, Data Collection or Processing: Nora Almutairi, Analysis or Interpretation: Sulaiman Mohammed Al-Mayouf, Khalid Alismail, Nora Almutairi, Literature Search: Sulaiman Mohammed Al-Mayouf, Nora Almutairi, Writing: Sulaiman Mohammed Al-Mayouf.

Conflict of Interest: No conflict of interest was declared by the authors.

Financial Disclosure: The authors declared that this study received no financial support.

\section{References}

1. Chalom E, Ross J, Athreya B. Syndromes and arthritis. Rheum Dis Clin North Am 1997;23:709-727.

2. Al-Mayouf SM. Familial arthropathy in Saudi Arabian children: demographic, clinical,and biochemical features. Semin Arthritis Rheum 2007:36:256-261.

3. Bulutlar G, Yazici H, Ozdoğan H, Schreuder I. A familial syndrome of pericarditis,arthritis, camptodactyly, and coxa vara. Arthritis Rheum 1986:29:436-438.

4. Laxer RM, Cameron BJ, Chaisson D, Smith CR, Stein LD. The camptodactyly arthropathypericarditis syndrome: case report and literature review. Arthritis Rheum 1986;29:439-444.

5. Offiah AC, Woo P, Prieur AM, Hasson N, Hall CM. Camptodactylyarthropathy-coxa varapericarditis syndrome versus juvenile idiopathic arthropathy. AJR Am J Roentgenol 2005;185:522-529.

6. Bahabri SA, Suwairi WM, Laxer RM, Polinkovsky A, Dalaan AA, Warman ML. The camptodactyly-arthropathy-coxa vara-pericarditis syndrome: clinical features and genetic mapping to human chromosome 1. Arthritis Rheum 1998;41:730-735.

7. Marcelino J, Carpten JD, Suwairi WM, Gutierrez OM, Schwartz S, Robbins C, Sood R, Makalowska I, Baxevanis A, Johnstone B, Laxer RM, Zemel L, Kim CA, Herd JK, Ihle J, Williams C, Johnson M, Raman V, Alonso LG, Brunoni D, Gerstein A, Papadopoulos N, Bahabri SA, Trent JM, Warman ML. CACP, encoding a secreted proteoglycan, is mutated in camptodactyly-arthropathy-coxa varapericarditis syndrome. Nat Genet 1999;23:319-322.

8. Rhee DK, Marcelino J, Al-Mayouf S, Schelling DK, Bartels CF, Cui Y, Laxer R, Goldbach-Mansky R, Warman ML. Consequences of diseasecausing mutations on lubricin protein synthesis, secretion, and posttranslational processing. J Biol Chem 2005;280:31325-31332.

9. Basit S, Iqbal Z, Umicevic-Mirkov M, Kamran UI-Hassan Naqvi $\mathrm{S}$, Coenen $\mathrm{M}$, Ansar $\mathrm{M}$, van Bokhoven $\mathrm{H}$, Ahmad W. A novel deletion mutation in proteoglycan-4 underlies camptodactylyarthropathycoxa-vara pericarditis syndrome in a consanguineous pakistani family. Arch Med Res 2011;42:110-114.
10. Alazami AM, Al-Mayouf SM, Wyngaard CA, Meyer B. Novel PRG4 mutations underlie CACP in Saudi families. Hum Mutat 2006;27:213.

11. Akawi N, Ali B, Al-Gazali L. A novel mutation in PRG4 gene underlying camptodactyly-arthropathy-coxa vara-pericarditis syndrome with the possible expansion of the phenotype to include congenital cataract. Birth Defects Res A Clin Mol Teratol 2012;94:553-556.

12. Bahabri S, Sakati N, Hugosson C, Hainau B, Al-Balla SR, Al-Mazyed A, Al-Dalaan A. Syndrome of camptodactyly, arthropathy and coxa vara (CAC syndrome). Ann Saudi Med 1994;14:479-482.

13. El-Garf A, Mahmoud G, Gheith R, Abd El-Aaty G, Abd El-Aaty H. Camptodactyly, arthropathy, coxa vara, and pericarditis syndrome among egyptians. J Rheumatol 2003;30:1081-1086.

14. Choi BR, Lim YH, Joo KB, Paik SS, Kim NS, Lee JK, Yoo DH. Camptodactyly, arthropathy, coxa vara, pericarditis (CACP) syndrome: a case report. J Korean Med Sci 2004;19:907-910.

15. Zwolak R, Majdan M, Skorski M, Chrapko B. Efficacy of radiosynoviorthesis and impact on chosen inflammatory markers. Rheumatol Int 2012;32:2339-2344.

16. Liepe K. Efficacy of radiosynovectomy in rheumatoid arthritis. Rheumatol Int 2012;32:3219-3224.

17. Chatzopoulos D, Moralidis E, Markou P, Makris V. Yttrium-90 radiation synovectomy in knee osteoarthritis: a prosective assessment at 6 and 12 months. Nucl Med Commun 2009;30:472-479.

18. Chrapko B, Zwolak R, Nocu A, Gołebiewska R, Majdan M. Radiation synovectomy with $90 \mathrm{Y}$ colloid in the therapy of recurrent knee joint effusions in patients with inflammatory joint diseases. Rheumatol Int 2007;27:729-734.

19. Rampersad A, Shapiro A, Rodriguez-Merchan E, Maahs J, Akins S, Jimenez-Yuste $V$. Radiosynovectomy: review of the literature and report from two haemophilia treatment centers. Blood Coagul Fibrinolysis 2013;24:465-470.

20. Van Kasteren M, Novakova I, Boerbooms A, Lemmens J. Long term follow up of radiosynovectomy with yttrium-90 silicate in haemophilic haemarthrosis. Ann Rheum Dis 1993;52:548-550.

21. Albuhairan I, Al-Mayouf SM. Camptodactyly-arthropathy-coxavarapericarditis syndrome in Saudi Arabia: Clinical and molecular genetic findings in 22 patients. Semin Arthritis Rheum 2013;43:292-296.

22. Murphy JM, Vanderhave KL, Urquhart AG. Total hip arthroplasty in adolescents with severe hip arthropathy and dysplasia associated with camptodactyly-arthropathy-coxa vara-pericarditis syndrome. J Arthroplasty 2012;27:1581.e5-8.

23. Kavakli K, Aydoğdu S, Omay SB, Duman Y, Taner M, Capaci K, Memiş A, Balkan C, Karapinar D. Long-term evaluation of radioisotope synovectomy with Yttrium 90 for chronic synovitis in Trukish haemophilics: Ismir experience. Haemophilia 2006;12:28-35.

24. Ozulker T, Ozulker F, Derin E, Altun M, Aydogan G, Turkkan E, Adaş $M$, Tonbul M, Ozpaçacı T, Sezgin F, Değirmenci H. The efficacy of 315 magnetic resonance imaging and $x$-ray in the evaluation of response to radiosynovectomy in patients with hemophilic arthropathy. Mol Imaging Radionucl Ther 2011;20:38-44.

25. Jahangier Z, Moolenburgh J, Jacobs J, Serdijn H, Bijlsma J. The effect of radiation synovectomy in patients with persistent arthritis: a prospective study. Clin Exp Rheumatol 2001;19:417-424. 